\title{
Abundance of Plankton in the Waters of Geger Beach, Badung Regency, Bali
}

\author{
Octria Vesensia ${ }^{1}$, I Wayan Arthana ${ }^{2}$, and Ayu Putu Wiweka Krisna Dewi ${ }^{3}$ \\ Department of Aquatic Resources Management, Faculty of Marine and Fisheries, Udayana University \\ Jl. Kampus Unud Bukit Jimbaran, Kuta Selatan, Badung, Bali \\ *Corresponding author: octriavesensiasimamora@gmail.com
}

\begin{abstract}
Geger Beach is located in Peminge traditional village area, Sawangan, Nusa Dua, Bali which is a tourism area and there is seaweed cultivation managed by local people. Such human activity will affect the quality of the waters which will result in an increase in nutrients and organic matter which can further lead to changes in the structure of plankton. The purpose of this study is to find out the types of plankton and the abundance of plankton found in the waters of Geger Beach using the pour method. This research was conducted in March 2021. Sampling is conducted once a week at three observation points. The total phytoplankton species obtained as many as 32 species consisting of 6 classes, namely Bacillariophyceae (23 genera), Xanthophyceae (1 genus), Cyanophyceae (3 genera), Ulvophyceae (1 genus), Conjugatophyceae or Zygnematophyceae (2 genera), Coscinodiscophyceae (2 genera). The dominant type of phytoplankton found during the study was the Gyrosigma fasciola species in the Bacillariophyceae class. Meanwhile, the total zooplankton obtained by 11 species consisting of 5 classes, namely Maxillopoda (3 genera), Hexanauplia (3 genera), Magnoliopsida, Branchiopoda and Copepoda (1 genus). The dominant type of zooplankton found during the study was the Cyclops sp. species in the Maxillopoda class. The average abundance of phytoplankton is 120 cells/l, while the average abundance of zooplankton is 20 cells/l. The average diversity value of phytoplankton is 2,7 , while the diversity of zooplankton is 1,4 . The average dominance index value of phytoplankton is 0,06 , while the average zooplankton dominance index is 0,25 .
\end{abstract}

Keywords Plankton; Abundance; Diversity; Dominance

\section{INTRODUCTION}

Indonesia has diverse biological resources, especially in coastal and oceanic areas,but the utilization of natural resources without considering the ecological balance will have a big impact on humans and also damage to existing ecosystems. One of them is plankton which has an important role in marine ecosystems. Plankton are microscopic organisms that hover in the water column and have a very weak swimming movement, so their movement is influenced by water currents. Plankton can be grouped into two large groups based on their type, namely phytoplankton and zooplankton [1]. Phytoplankton are the main producers of water and have an important role to determine productivity in a water, because it serves as a producer for the process of life or energy transfer through the food chain in the water [2]. Zooplankton is a biota that plays an important role in secondary productivity, so it can be expressed as a liaison of primary producers with higher consumers [3].

The presence of organisms in the waters, especially plankton, is strongly influenced by the physical-chemical parameters of the waters because plankton are the first organisms to respond to changes in the quality of those waters [4]. The very complex aquatic conditions resulting from various human activities and the entry of organic matter to the coast will affect the quality of water, which further affects the presence of plankton. The existence of plankton quantitatively and qualitatively can be used to determine the fertility of a water, namely by measuring the abundance of plankton in Geger Beach.

Geger Beach is located in peminge traditional village area, Sawangan, Nusa Dua, Badung Regency, Bali Province. Geger Beach is a tourism area and there is seaweed cultivation managed by local residents. Such human activities will increase the input burden in the form of domestic waste and industrial waste. The increasing input burden of human activity can affect the quality of the waters that will increase nutrients and organic matter which will further lead to changes in the physical-chemical quality of water and plankton structures [4]. Therefore, it is necessary to conduct research on the abundance of plankton in the waters of Geger Beach.

\section{RESEARCH METHODS}

\section{Time and Location of the Research}

The research was conducted in March 2021. This research took place in the waters of Geger beach located in Paminge Traditional Village, Sawangan, Nusa Dua, Badung Regency, Bali Province. The sampling was conducted three times, namely on March 13, 2021, March 20, 2021, March 27, 2021. Data collection was conducted 
at three research points consisting of tourist areas (point 1), seaweed cultivation areas (point 2), areas close to the hotel industry (point 3). The research location map is shown in Figure 1.

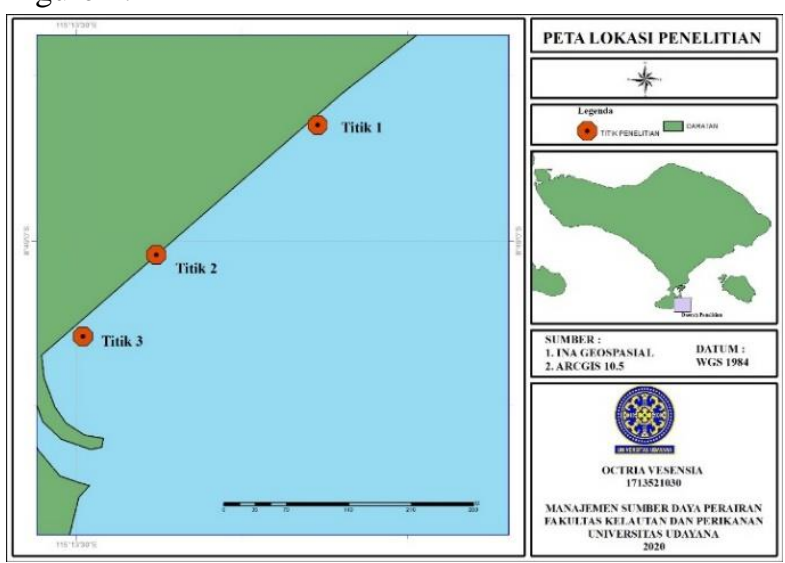

Figure 1. Map of Sampling Location

\section{Tools and Materials}

The tools used during the study were net plankton (phytoplankton $40 \mu \mathrm{m}$ and zooplankton $125 \mu \mathrm{m}$ ), stationery, GPS, disk secchi, refractometer (ATAGO, Master-S/MiIIM Cat. 2493), DO meter (LUTRON, DO5509), optic lab, binocular microscope (OLYMPUS CORPORATION, CX-21FS1), sample bottle, Sedge raftwicker,drip pipette, camera (SAMSUNG, A51), plankton identification book, sample bottle, bucket (5 L), drip pipette, and laptop. The materials used are aquedest, formaldehyde $4 \%$, lugol $4 \%$, water samples.

\section{Plankton Sampling Methods}

Plankton sampling using purposive sampling method is data retrieval with certain reasons and considerations to obtain samples that represent the overall research location picture [5]. Sampling is done by pour method. Plankton water samples are taken using buckets with a volume of 5 liters and filtered using net plankton as much as 10 times. The filtered water is then transferred into the sample bottle, then given 20 drops of $4 \%$ lugol and 7 drops of formaldehyde $4 \%$. The sample bottle is labeled according to the point then put in a cool box and iced.

\section{Water quality measurement methods}

Water quality measurement is done at the predetermined location point with repetition 3 times, water quality parameters measured in situ (temperature, salinity, $\mathrm{pH}$, and DO) and ex situ (nitrates and phosphates) are conducted at the Fisheries Science Laboratory of the Faculty of Marine Affairs and Fisheries, Udayana University.

\section{Identification of Plankton}

Plankton identification was conducted in the Laboratory of the Faculty of Marine Affairs and Fisheries of Udayana University. The sample bottle is stirred first, then taken 1 $\mathrm{ml}$ using a drop pipette into the Sedgewick rafter, then the sample is observed using a $100 \times$ magnification binocular microscope. Plankton observation using clean broom method with repetition 3 times. Identification is carried out at the species level. Identification guide using marine plankton book Plankton a Practical Guide [6], Guide to the Coastal and Surface Zooplankton of The South-Western Indian Ocean [7].

\section{Data Analysis \\ Plankton Abundance Analysis}

The abundance value of plankton is used to determine the amount of plankton at each volume or in cells per liter. Calculated based on formula [8].

$$
\mathrm{N}=\mathrm{n} \times\left(\frac{\mathrm{Vr}}{\mathrm{V}_{\mathrm{o}}}\right) \times\left(\frac{1}{\mathrm{Vs}_{\mathrm{s}}}\right)
$$

Where $\mathrm{N}$ is the number of cells per liter (ind/l); $n$ is the number of cells observed or found; $\mathrm{Vr}$ is the volume of filtered water $(\mathrm{ml})$; Vo is the observed volume of water $(\mathrm{ml})$; Vs is the volume of filtered water (1).

\section{Plankton Diversity Index}

The plankton diversity index is a mathematical overview to facilitate the analysis of information about the type and number of organisms. Plankton diversity index calculated using Shannon-Wienar index formula [9].

$$
\mathrm{H}^{\prime}=-\sum_{i=1}^{n}(p i \ln p i), \mathrm{Pi}=\frac{n i}{N}
$$

Where $\mathrm{H}^{\prime}$ is Diversity of types; $\mathrm{Pi}$ is the proportion of abundance of the i-plankton species; ni is the i-number of individual types of the plankton; $\mathrm{N}$ is the total number of individual plankton.

The total range of diversity index can be categorized into 3 sections as listed below [9]:

$\mathrm{H}^{\prime}<2.3026$ is low diversity; $2.3026<\mathrm{H}^{\prime}<6.9078$ is moderate diversity; $\mathrm{H}^{\prime}>6.9078$ is high diversity.

\section{Dominance Index}

The dominance index is used to see the presence of dominance by certain types of plankton populations on the coast. The formula of the dominance index by [10].

$$
\mathrm{D}=\sum_{i=1}^{n}\left(\frac{n i}{N}\right)^{2}
$$

Where $\mathrm{D}$ is the dominant index; ni is the i-number of individuals; $\mathrm{N}$ is the total number of individuals.

Dominant index values (D) range from 0 to 1 . When the $\mathrm{D}$ value is close to 0 it means that almost no individual dominates. Whereas if the value of $\mathrm{D}$ is close to 1 means that there is a certain type of dominance in a water.

\section{Water Fertility Rate}

The fertility rate of the waters can be found from various characteristics of the waters, one of which is the abundance of plankton. To suspect trophic status based on the abundance of plankton guided by [11] namely: 
Oligotropic waters are low fertility rate with an abundance of phytoplankton 0-2000 cells/l and zooplankton 1 cell/l; Mesotropic waters are moderate fertility rate with an abundance of phytoplankton 200015000 cells/l and zooplankton 1-500 cells/l; Eutropic waters are high fertility rate with an abundance of phytoplankton $>15000$ cells/l and zooplankton $>500$ cells/l.

\section{RESULT AND DISCUSSION}

\section{Composition of Phytoplankton}

The results of the identification of plankton in the coastal waters of geger found 32 species of phytoplankton consisting of 6 classes, Namely Bacillariophyceae (23 genera), Xanthophyceae (1 genus), Cyanophyceae (3 genera), Ulvophyceae (1 genus), Conjugatophyceae or Zygnematophyceae (2 genera), Coscinodiscophyceae (2 genera) (figure 2).

The composition of phytoplankton species found during observation was dominated by the species Gyrosigma fasciola, Pleurosigma sp. and Stenopterobia sp. derived from the Bacillariophyceae or diatom class. The Bacillariophyceae class has a composition of $82 \%$. It is suspected that the Bacillariophyceae class has better adaptability compared to other classes of plankton. [12] states that Bacillariophyceae-class plankton can withstand changes in aquatic quality environmental conditions and have greater reproductive capabilities compared to other phytoplankton groups and make good use of nutrient content. According to [13] added that the Bacillariophyceae class is quite widely spread and can live in a variety of different types of habitats and its existence tends to dominion of open sea waters, beaches and estuaria.

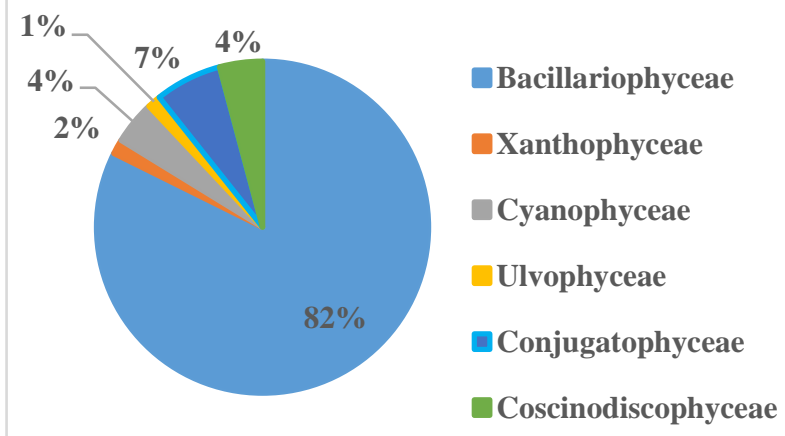

Figure 2. Composition (\%) of Phytoplankton on the Geger Beach

\section{Composition of Zooplankton Species}

The results of the identification of plankton in the coastal waters of geger found 11 species of zooplankton obtained consisting of 5 classes, namely Maxillopoda (3 genera), Hexanauplia (3 genera), Magnoliopsida (1 genus), Branchiopoda (1 genus) and Copepoda (1 genus) (figure 3).

The composition of zooplankton found during observation is dominated by the species Cyclops sp. in the Maxillopod class, which is $47 \%$. The abundance of zooplankton in the Maxillopod class is certainly also supported by the availability of phytoplankton in the waters, where the presence of phytoplankton in the waters affects the presence of zooplankton in the food chain. This is supported by [14] and [15] that, the abundance of zooplankton depends on the availability of food, the presence of pressure of predatory and predatory fish, water temperature, dissolved oxygen, wind gusts that trigger the movement of water as well as the interaction between biotic and other abiotic factors.

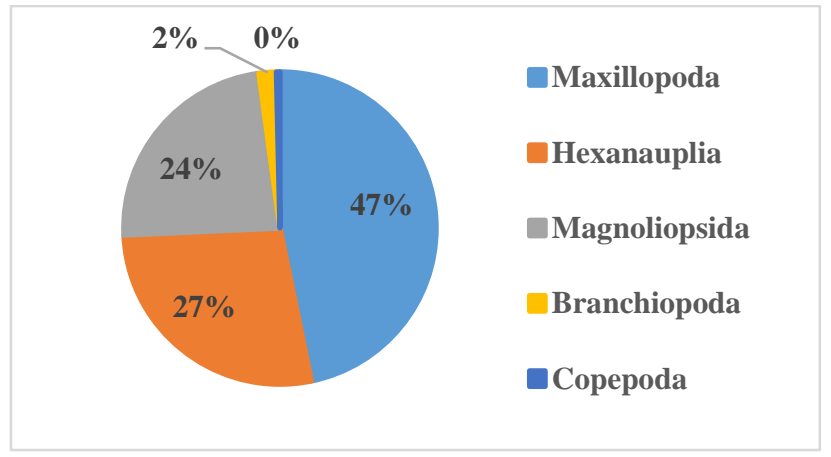

Figure 3. Composition (\%) of Zooplankton on the Geger Beach

\section{Plankton Abundance}

The average abundance of phytoplankton at the first point was 112 cells/l,at the second point it was 130 cells/1 and the third point was 118 cells/l. The highest average value of phytoplankton abundance is found at the second point which is the seaweed cultivation area. This is because, the results of analysis of nutrient conditions, such as nitrates and phosphates that show that the largest abundance of nutrients are found at thatpoint. According to [16] that, nutrient abundance is an important factor that greatly influences the abundance and number of phytoplankton types. The lowest average amount of phytoplankton abundance is found at the first point which is the tourist area. This is because, there are treatment of water attractions such as swimming and so on. According to [17] that, tourist areas are influenced by water attraction activities where wind speed and current direction can affect the abundance of phytoplankton.

The average abundance of zooplankton at the first point is 19 cells/l, at the second point it is 22 cells/ 1 and the third point is 20 cells/l. The difference in abundance of zooplankton at each observation point found is closely related to the availability of phytoplankton. [18] and [19] states that the $\mathrm{N}: \mathrm{P}$ ratio plays an important role in determining the abundance of zooplankton. This is because the N:P ratio is a limiting factor for phytoplankton growth, where plankton are food for zooplankton.

The fertility rate of the waters can be seen through the abundance of [11] dividing the waters into three parts namely oligotropic waters (phytoplankton 0-2000 cells/1 and zooplankton 1 cell/1), mesotropic waters (phytotropics plankton 2000-15000 cells/l and zooplankton 1-500 cells/l), eutropic waters (phytoplankton $>15000$ cells/l and zooplankton $>500$ cells/l). Based on this classification, the waters of Geger Beach have an abundance of 
phytoplankton of 361 cells/1 classified in oligotropic fertility or low fertility rates, while the abundance of zooplankton has a value of 61 cells/l is mesotropic waters or moderate fertility rate.

\section{Plankton Diversity}

The stability of the community in the water can be described from the value of the diversity index $\left(\mathrm{H}^{\prime}\right)$. The average index value of phytoplankton diversity at the first point was 2,7, in the second point was 2,9 and the third point was 2,6 . The average phytoplankton homogeneity index value at each observation point is 2,7 . This value indicates the diversity of species in the waters of Geger Beach, classified as moderate, this is supported by [9] that the value of diversity is ranging from 2.3026 to 6.9078 . The difference in the value of diversity index that varies in the waters of Geger Beach, caused by environmental factors such as the availability of nutrients such as phosphates and nitrates, as well as the ability of each type of phytoplankton to adapt to the existing environment, is in accordance with the statement of [20], that water physics factors as well as the availability of nutrients and also the utilization of different nutrients from each individual can affect the value of the diversity index.

The average diversity index $\left(\mathrm{H}^{\prime}\right)$ value of zooplankton at the first point is 1,4 , in the second point is 1,6 and the third point is 1,3 . The average zooplankton homogeneity index value is 1,4 . This value indicates that species diversity is relatively low, this is in accordance with [9], that the value of low diversity is below the value of 2,3026, meaning small species diversity and low community stability.

\section{Plankton Domination}

The dominant average index (D) of phytoplankton at the first point was 0,06 , in the second point was 0,07 and the third point was 0,05 . The average value of the phytoplankton dominance index is 0,06 . The dominant index values at the three study sites were not dominating species because the standard deviation in phytoplankton dominance was 0,02 to 0,04 . This is reinforced by [21] that, if the dominant value of the value of 0 means in the community structure there are no species that are extremely donating other species.

The average index of dominance (D) of zooplankton at the first point was 0,23 , in the second point was 0,31 and the third point was 0,22 . The average zooplankton dominance index value is 0,25 . This indicates the dominance of species in the waters of Geger Beach obtained close to zero, meaning that no one is dominating other species. This is based on [22] that, the range of dominant index values of $0-0,50$ indicates that the area is low dominance. This is reinforced by [21] that, the dominant index value ranges from $0-1$, when the dominant index value $(\mathrm{C})$ is close to 0 means in the biota community structure that is observed there are no species that extremely domineering other species.

\section{Water Quality Parameters}

Table 1 shows the results of measurement of physical and chemical parameters in the waters of Geger Beach. The temperature range in the waters of Geger Beach ranges from 26,4 to $31,9^{\circ} \mathrm{C}$. According to [23] and [15], the temperature is still very optimal for the growth of plankton in the waters of Geger Beach where the optimal temperature range for the growth and life of phytoplankton and zooplankton can range from $15-35^{\circ} \mathrm{C}$.

Salinity values at each point range from 28 to $31 \mathrm{ppt}$. The value states that seawater salinity tends to be normal for plankton life. This is in accordance with the opinion of [24] which states that if the salinity of sea water 20 to $32 \mathrm{ppt}$ then stable for plankton life.

The $\mathrm{pH}$ range shown at each point is 7,01 to 7,29 . This value indicates that the waters at Geger Beach are neutral. The $\mathrm{pH}$ value found is appropriate for the growth and development of plankton life. This is supported by [25] which states that the ideal $\mathrm{pH}$ value for aquatic organism life including plankton generally ranges from 7 to 8,5 .

The value of DO (Dissolved Oxygen)obtained ranges from 8 to $8.8 \mathrm{mg} / \mathrm{l}$. This value shows good value to support the life of plankton growth and development. This is in accordance with [26], that values ranging $>6,5 \mathrm{mg} / \mathrm{l}$ indicate optimum values to support plankton life.

Nitrate concentrations in the waters of Geger Beach range from 0,20 to $0,93 \mathrm{mg} / \mathrm{l}$. According to [27], nitrate values exceeding $0,03 \mathrm{mg} / \mathrm{l}$ are the optimum values for phytoplankton growth. Judging from the fertility rate of the waters, nitrate levels of 0,20 to $0,93 \mathrm{mg} / \mathrm{l}$ are classified as high (eutrophic) [28].

TABLE 1

WATER QUALITY MEASUREMENT RESULTS

\begin{tabular}{|c|c|c|c|c|}
\hline \multirow{2}{*}{ No. } & Parameters & \multicolumn{3}{|c|}{ Water Quality Measurement Results } \\
\cline { 3 - 5 } & & Point 1 & Point 2 & Point 3 \\
\hline 1. & $\begin{array}{c}\text { Temperature } \\
\left({ }^{\circ} \mathrm{C}\right)\end{array}$ & $\begin{array}{c}31,5-31,8 \\
{ }^{\circ} \mathrm{C}\end{array}$ & $\begin{array}{c}28,2-31,9 \\
{ }^{\circ} \mathrm{C}\end{array}$ & $26,4-28,8^{\circ} \mathrm{C}$ \\
\hline 2. & $\begin{array}{c}\text { Salinity } \\
(\mathrm{ppt})\end{array}$ & $\begin{array}{c}28-30 \mathrm{ppt} \\
\text { nyyy }\end{array}$ & $28-29 \mathrm{ppt}$ & $30-31 \mathrm{ppt}$ \\
\hline 3. & $\mathrm{pH}$ & $7,14-7,29$ & $7,04-7,14$ & $7,01-7,08$ \\
\hline 4. & DO $(\mathrm{mg} / \mathrm{l})$ & $8-8,8 \mathrm{mg} / 1$ & $8-8,6 \mathrm{mg} / 1$ & $8,1-8,8 \mathrm{mg} / 1$ \\
\hline 5. & $\begin{array}{c}\text { Nitrates } \\
(\mathrm{mg} / \mathrm{l})\end{array}$ & $\begin{array}{c}0,22-0,60 \\
\mathrm{mg} / 1\end{array}$ & $\begin{array}{c}0,26-0,93 \\
\mathrm{mg} / 1\end{array}$ & $0,20-0,29 \mathrm{mg} / 1$ \\
\hline 6. & $\begin{array}{c}\text { Phosphate } \\
(\mathrm{mg} / \mathrm{l})\end{array}$ & $\begin{array}{c}0,05-0,13 \\
\mathrm{mg} / 1\end{array}$ & $\begin{array}{c}0,07-0,45 \\
\mathrm{mg} / 1\end{array}$ & $0,03-0,08 \mathrm{mg} / 1$ \\
\hline
\end{tabular}

Phosphate concentrations in the waters of Geger Beach ranged from 0,05 to $0,45 \mathrm{mg} / \mathrm{l}$. Phosphate levels in the waters of Geger Beach are optimum and viable for phytoplankton growth. The optimum phosphate levels for phytoplankton growth are $0,09 \mathrm{mg} / \mathrm{l}$ to $1,80 \mathrm{mg} / \mathrm{l}$ [29]. 
Based on the fertility rate of the waters, phosphate levels of 0,05 to $0,45 \mathrm{mg} / \mathrm{l}$ are classified as high (eutrophic) [30].

\section{CONCLUSION}

Measurements of water quality, such as temperature parameters, $\mathrm{pH}$, salinity, DO, nitrate and phosphate levels indicate the waters at Geger Beach were found suitable for the growth and life development of plankton., The number of plankton species obtained in the waters of Geger Beach as many as 43 species consisting of 32 species of phytoplankton consisting of 6 classes, Bacillariophyceae (23 genera), Xanthophyceae (1 genus), Cyanophyceae (3 genera), Ulvophyceae (1 genus), Conjugatophyceae or Zygnematophyceae (2, Coscinodiscophyceae (2 genera). The composition of phytoplankton found during observation is dominated by the species Gyrosigma fasciola in the Bacillariophyceae class. Meanwhile, the total zooplankton obtained by 11 species consisting of 5 classes, namely Maxillopoda (3 genera), Hexanauplia (3 genera), Magnoliopsida (1 genus), Branchiopoda (1 genus) and Copepoda (1 genus). The composition of zooplankton found during observation is dominated by the species Cyclops sp. maxillopoda class.

The average abundance value of phytoplankton is 120 cells/l, while the average abundance of zooplankton is 20 cells/l. The average diversity value of phytoplankton is 2,7 , while the diversity of zooplankton is 1,4 . The average dominance index of phytoplankton is 0,06 , while the zooplankton average dominance index is 0,25 .

\section{ACKNOWLEDGMENT}

The author thanked Prof. Ir. I Wayan Arthana, MS., Ph.D as the supervisor I, Mrs. Ayu Putu Wiweka Krisna Dewi, S.ST. Pi., M.P as supervisor II, Mrs. Dra. Ni Luh Watiniasih, M.Sc. Ph.D as examiner I, Mr. I Wayan Darya Kartika, S.Pi., M.Si as tester II who has spent time and always patient in providing guidance, advice and input in the completion of this research and both parents of writers who always provide compassion and motivation and support both moral and material so that the creation of this journal can run smoothly.

\section{REFERENCES}

[1] Thoha, H. and Amri. 2011. Composition and Abundance of Phytoplankton in the Waters of South Kalimantan. Journal of Oceanology and Limnology in Indonesia (OLDI). 2 (7): 372-380.

[2] Soeprobowati, T. R., \&suedy, S. W. A. 2011. Lake Rawapening Phytoplankton Community, 19,7 \pm 30 .
[3] Melay S, Rahalus KD. 2014. Zooplankton Community Structure in Mangrove Ecosystem in Ohoi/ Kolser Village, Southeast Maluku. Biopendix. 1(1): 101-110.

[4] Abida, I. W. 2010. Community Structure and Abundance of Phytoplankton in the Waters of the Porong Sidoarjo River estuary. Marine Journal, 3,3640.

[5] Sugiyono. 2016. Quantitative, Qualitative and Mixed Methods Research Methods. Bandung: Alfabeta.

[6] Newell, G.E., and Newell, R.C. 1977. Marine Plankton a Practical Guide. London, United Kingdom: Departement of Zoology, Queen Mary Collage University.

[7] Conway, D.V.P., White, R.G., Hugues, D.C.J., Gallienne, C.P., and Robins. 2003. (1st ed.). Guide to The Coastal And Surface Zooplankton of The South Western Indian Ocean. United Kingdom: Marine Biological Association.

[8] Fachrul, M.F. 2012. Sampling Method bioecology. Jakarta, Indonesia: PT Bumi Aksara.

[9] Usman, M. S. J. D. Kusen. and J. R. S. L. Rimper. 2013. Plankton Community Structure in the Waters of Bangka Island, North Minahasa Regency. Journal of Tropical Coasts and Seas. 2 (1): 51-57.

[10] Munthe, Y. V., Riris, A, Isnaini. 2012. Community Structure and Distribution of Phytoplankton in the Breech Waters of South Sumatra. Maspari Journal. 4(1):122-130.

[11] Goldman CR., and Horne AJ. 1994. Limnology. Mc. Graw Hill Book Co. USA.

[12] Nurfadillah, Damar, and Adiwilaga. 2012. Phytoplankton Community in the Waters of The Fresh Sea Lake of Central Aceh Regency, Aceh Province. Depik, 1(2), 93-98.

[13] Faturohman, I., Sunarto, I. Nurruhwati. 2016. Correlation of Plankton Abundance with Sea Water Temperature Around Cirebon Power Plant. Journal of Fisheries and Marine Affairs. 8(1):115-122.

[14] Humaira R, Izmiarti, Zakaria I.J. 2016. Composition and Structure of Zooplankton Communities in the Litoral Zone of Lake Talang, West Sumatra. Proceedings of the National Seminar of the Indonesian Biodiversity Society. 2(1): 55-59.

[15] Maniagasi R, Tumembouw SS, Mundeng Y. 2013. Analysis of the Quality of Water Chemistry Physics in the Fish Cultivation Area of Lake Tondano, North Sulawesi Province. Aquaculture. 1(2): 29-37.

[16] Radiarta, I N., \& Erlania. 2015. Index of Water Quality and Nutrient Distribution around Integrated Marine Cultivation in Ekas Bay, West Nusa Tenggara: Important Aspects of Seaweed Cultivation. Aquaculture Research Journal, 10(1): 141-152. 
[17] Garno, Y.S. 2008. Water Quality and Phytoplankton Dynamics in the Waters of Harapan Island. Indonesian Hydrosfir Journal, 3: 87-94.

[18] An XP, Du ZH, Zhang JH, Li YP, Qi JW. 2012. Structure of the Zooplankton Community in Hulun Lake, China. Procedia Environmental Sciences. 13: 1099-1109.

[19] Rais FF, Djayus Y, Muhtadi A. 2015. Plankton Community Structure in Lake Pondok Lapan Naman Jahe Village Salapian District Langkat. Journal Aquacoastmarine. 9(4): 34-42.

[20] Yazwar. 2008. Plankton Diversity and Its Association with Water Quality in Lake Toba Parapat. Medan: Thesis Graduate School, University of North Sumatra.

[21] Amin M, Utojo. 2008. Composition and Diversity of Plankton Species in the Waters of Kupang Bay, East Nusa Tenggara Province. Torani Vol. 18 (2) : 129 135.

[22] Ludwig, J.A D and Reynolds, J.V. 1988. Statistical Ecology a Primer in Methods and Computing. John Wiley and Sons. New York.

[23] Aryawati, R. 2007. Abundance and Distribution of Phytoplankton in the Waters of Berau, East
Kalimantan. Postgraduate. Bogor Agricultural Institute.

[24] Sachlan, M. 1972. Planktonologi. Correspodence Course Centre. Jakarta.

[25] Barus, T.A. 2004. Introduction to Limnology: The Study of Terrestrial Aquatic Ecosystem. USU Press, Medan.

[26] Kristianto, P. 2004. Industrial Ecology. PETRA Christian University, Surabaya. ANDI. Yogyakarta.

[27] Karyono dan Pandi. 1977. Several Observation on the Problem of Microcystis Algae Explosion in Relation to Water Quality. Journal of Ecology and Development No. 5 of 1977. 110-117 p.

[28]Zulfia, N. dan Aisyah. 2013. The Trophic Status of the Pening Swamp Waters in Terms of Nutrient Content $\left(\mathrm{NO}_{3}\right.$ and $\left.\mathrm{PO}_{4}\right)$ and Chlorophyll-a. Bawal. 5(3): 189199.

[29] Malaha, K.P. 2004. The Level of Water Fertility Based on the Nutrient Content of Nitrate $(N)$ dan Phosphate $(P)$ in the Waters of the River Balandete, Kolaka Regency. Essay. FPIK. UNHALU. Kendari..

[30] Effendi, H. 2003. Water Quality Assessment: For the Management of Aquatic Resources and the Environment. Yogyakarta: Kanisius. 